\title{
States and Markets: Sociology of Public Policy in Canada
}

\author{
by Susan A. McDaniel and Seong-gee Um \\ Don Mills, ON: Oxford University Press 2015 \\ ISBN 978-0-19-544280-9 \\ Softcover $\$ 58.95,256$ pp.
}

\author{
Reviewed by Anthony C. Masi \\ Desautels Faculty of Management, McGill University
}

This monograph, in the OUP series "Themes in Canadian Sociology," is well-suited as a companion text in introductory sociology courses or in upper-division offerings in any discipline dealing with public and social policies. While prevalently Canadian material is presented, there is sufficient information on other countries to place Canada in comparative perspective, which the authors often do.

McDaniel and Um have designed the volume with a decidedly pedagogical approach. Each chapter starts with specific learning objectives, briefly introduces its topic, delves into the arguments, sums up, provides questions for critical thought, and concludes with suggested readings and websites. Throughout the text, words and phrases in bold are defined fully in the glossary. In addition, there is a set of references that have been directly cited in the book or influenced its development of arguments.

The eight chapters follow a logical path: (1) sociological views of public policy, (2) theories of public policy, (3) present challenges framed by the past and an anticipated future, (4) the meaning of "security" for Canadians, (5) states and markets as forces for change, (6) equality and inclusion under policy retrenchment, (7) creating a new policy agenda, and (8) summary of themes and predicting challenges.

Readers are reminded, early and often, that Canada's "public policy architecture" is framed by a macro-level context: globalization, trends in industrial and occupational structures, changes in the economy and labour market, demographic shifts, and fluctuating discourses and paradigms regarding approaches to public and social policies. The authors are equally clear in pointing out that their book is not about the "policy process," does not go into depth about the political economy, political sociology, economics, social work, or political science of public and social policies. Neither does it contain comprehensive micro-level analyses of specific policies. Rather, the text contains illustrative examples of particular policies that highlight the sociological points under discussion.

McDaniel and Um (p. 2) consider that public policy "encompasses all actions taken by states (governments writ large) presumably in the public interest. It can include everything from economic or monetary policy to the regulation of pets." They stick to the middle ground. Social policies are treated as a subset of more general public policies. The authors define "the state" as the only legitimate institution that can tax the citizenry and use force to ensure order, both to the benefit of society. States accumulate resources and then reallocate them for the public good. The "welfare state" is taken to mean the sum of economic policies and social programs. It is variable across time and national boundaries, and as in the case in Canada, across provincial jurisdictions. The other institution that accumulates and allocates resources is, of course, "the market". This juxtaposition allows the authors to contrast social versus market citizenship and to outline the conflicts that emerge in formulating public policies.

For the authors, theories are simply explanations of why things happen, so they quickly move on to concrete expressions of what public policies actually are: reflections of a society's goals, what it values from its citizens, 
and its orientation to how to achieve both. Policies are the collective products of belief systems, negotiations, bargaining, trading interests, compromises, and political processes among a society's actors and institutions ( $\mathrm{p}$. 19).

Complex sociological approaches are condensed into comprehensible paragraphs, leaving ample room for criticism that they have given the short-shrift to this or that perspective. In fact, by focusing on some of the grander schemes, the authors have missed opportunities to tie public policy to theories of the middle-range.

The book contains a considerable dissection of the extensive, yet still very inconclusive, debate about "varieties of capitalism." In addition to states and markets, other social actors play a role in determining the existence and shape of public policies: families, voluntary organizations, and (some aspects of) enterprises. A further useful pedagogical tool that McDaniel and Um employ throughout the volume is "the box" or sidebar. There is a worthwhile discussion, in the box and in the text (p. 31), that conceptualizes service provision as a "care diamond": purchased (markets), reciprocal (families/kin), collective (communities/voluntary associations), and solidarity (state). That diamond is extendable to a "welfare pentagon" when enterprises provide supplementary services not elsewhere available.

McDaniel and Um develop the recurrent problem of tension between the egalitarian ideal of citizenship in democracies and the reality of (growing) economic inequalities under free-market capitalism. In the face of uncertainty, what do citizens expect from their politicians? For them, globalization has driven a wedge between a once dense network of social welfare policies and the requirements of a more flexible workforce. Canada's experience, while less dramatic than elsewhere in the Anglophone world, has been what the authors characterize as a neoliberal reduction in the apparatus of the state. Enter the counter-ideology.

This retreat from Keynesianism, that had emphasised risk protection and redistribution in favour of relying on competitive market forces for the efficient allocation of resources, forms the core of the substantive chapters of this volume. McDaniel and Um develop three lines of argument. First, the "caring and sharing" approach, based on reciprocity, inclusion, and trust, which the governments took over from churches and other voluntary associations to form "welfare state programs," has been under attack since the 1970s. Neoliberals consider it to be the cause of, not the solution to, inequalities. Second, the authors insist that the "lack of policy," itself a public policy stance (p. 41), is being increasingly employed by (conservative) governments. Third, and following Stiglitz (2012), over the last four decades or so, too little attention has been given to the following facts: (a) markets have not been stable, efficient, or self-regulating, (b) states have been unable to provide appropriate correctives to market failures, and (c) citizens in the advanced democracies, including Canadians, have become increasingly skeptical regarding the fairness of their political and economic systems and the people who lead them.

The discussion of "embedded taxation" (p. 61-74) tries to link public tax and transfer policies to differences in well-being among Canadians in different provincial jurisdictions, as well as between Canada and other OECD countries. These are complex matters. How are tax burdens, ratios of taxes to gross domestic product (GDP), ratios of debt to GDP, and differences in powers and responsibilities between federal and provincial governments related to a variety of outcome measures? Can the latter be mediated by a variety of policies and/or local expression of intentions? The potential for confusion is illustrated by the data on international tax burden (Table 4.1, p. 63). These data deal only with "central governments," making Canada appear rather moderate in generating revenues from its citizens and residents. However, given the constitutional division of powers, when this information is supplemented with provincial income taxes (p. 66), the burden on Canadians increases. Further, no mention is made of the fact that in some central, rather than federal systems, property taxes are included in those tax rates. In Canada, of course, housing taxes are levied at an even lower level, being generally a municipal matter.

There is a discussion in Chapter 4 of the differences between "Thatcherism" (lower social expenditures, lower taxes, privatization, smaller government) and "Reaganomics" (reduced growth in government expenditures, reduced marginal tax rates, reduced regulation, and reduced inflation). McDaniel and Um link these approaches to the Mulroney, Chrétien, and Harper modifications of several Canadian federal programs, including employment insurance, as well as to some provincial attempts at workfare. In their exegesis of "devolution" (p. 96), the authors missed the opportunity to contrast it to the principle of subsidiarity, or to more fully engage with the notion of trade-offs when resources are truly scarce. 
The authors return to their theoretical approaches (Marx, Weber, Durkheim, Marshall) in discussing poverty, income inequality, and socio-economic mobility. They also include a set empirical indicators (low-income cutoffs, low income measures, market basket measures) and provide illustrations of various policy instruments (Old Age Security, Canada/Quebec Pension Plan, Guaranteed Income Supplement, social security programs). Barriers are outlined that seem to prevent the policies from more fully adjusting the outcomes: technological advances, differences in jurisdictional minimum wage rates, performance bonuses, declining unionization, and various socio-demographic changes like family structure and assortative mating patterns.

McDaniel and Um (p. 170-71, 182) use the 2012 Quebec student protest against proposed increases in university tuition as an illustration of the "vox populi" ensuring continued accessibility to higher education in that Province. As noted above, the authors did not intend to do microanalysis of any specific policy, but the facts of this case clearly deserved more attention than contained in their illustration. Tuition rates did not go up, but neither did government support, forcing universities to cut budgets and/or to seek alternative sources of revenue. Access was not enhanced. Fact: Quebec remains with very low tuition rates, but still has very low university participation rates!

There are several demography-related entries in the index: population ageing, generation boomerang, assortative matting, First Nations life expectancy, Census of Canada (2011 long-form controversy). In the book, demographers will also find several policy examples of direct relevance: ageing population structures and pension policies, international and inter-provincial migration, childcare and other family measures, life course transitions. Each would have benefited from more data, better illustrations, and fuller discussion.

Notwithstanding some shortcomings, this is book nicely fills a gap by providing an introduction to the sociology of public policy, illustrated with Canadian examples, some important ones that are discussed in detail.

\section{References}

Stiglitz, J.E. 2012. The Price of Inequality: How Today's Divided Society Endangers Our Future. New York: W.W. Norton \& Company. 